\title{
Heat shock protein 90/Akt pathway participates in the cardioprotective effect of exogenous hydrogen sulfide against high glucose-induced injury to $\mathrm{H9c2}$ cells
}

\author{
XIAO KE ${ }^{1,2^{*}}$, JINGFU CHEN $^{3 *}$, LONGYUN PENG $^{4}$, WEI ZHANG ${ }^{5}$, YIYING YANG $^{5}$, XINXUE LIAO $^{4}$, \\ LIQIU MO ${ }^{6}$, RUIXIAN GUO ${ }^{7}$, JIANQIANG FENG ${ }^{6}, \mathrm{CHENGHENG} \mathrm{HU}^{4}$ and RUQIONG NIE ${ }^{2}$
}

${ }^{1}$ Department of Cardiology, Shenzhen Sun Yat-sen Cardiovascular Hospital, Shenzhen; ${ }^{2}$ Department of Cardiology, Sun Yat-sen Memorial Hospital, Sun Yat-sen Universtity, Guangzhou, Guangdong; ${ }^{3}$ Department of Cardiovascular Medicine and Dongguan Cardiovascular Institute, The Third People's Hospital of Dongguan City, Dongguan; ${ }^{4}$ Department of Cardiology,

The First Affiliated Hospital, Sun Yat-sen University; ${ }^{5}$ Department of Cardiovasology and Cardiac Care Unit (CCU),

Huangpu Division of The First Affiliated Hospital, Sun Yat-sen University; ${ }^{6}$ Department of Anesthesiology,

Huangpu Division of The First Affiliated Hospital, Sun Yat-sen University; ${ }^{7}$ Department of Physiology,

Zhongshan School of Medicine, Sun Yat-sen University, Guangzhou, Guangdong, P.R. China

Received October 3, 2015; Accepted January 17, 2017

DOI: 10.3892/ijmm.2017.2891

\begin{abstract}
It has been reported that exogenous hydrogen sulfide $\left(\mathrm{H}_{2} \mathrm{~S}\right)$ protects against high glucose $(\mathrm{HG})$-induced cardiac injury and has a modulatory effect on heat shock protein (HSP) and Akt, which play a cardioprotective role. In this study, we examined whether the HSP90/Akt pathway contributes to the protective effects of exogenous $\mathrm{H}_{2} \mathrm{~S}$ against HG-induced injury to H9c2 cardiac cells. Our results revealed that the exposure of $\mathrm{H} 9 \mathrm{c} 2$ cardiac cells to $35 \mathrm{mM}$ glucose (HG) for 1 to $24 \mathrm{~h}$ decreased the expression of HSP90 and markedly reduced the expression level of phosphorylated (p)-Akt in a time-dependent manner. Co-exposure of the cells to HG and geldanamycin (GA; an inhibitor of HSP90) aggravated the inhibition of the p-Akt expression level by HG. Of note, treatment of the cells with $400 \mu \mathrm{M}$ NaHS (a donor of $\mathrm{H}_{2} \mathrm{~S}$ ) for 30 min prior to exposure to HG significantly attenuated the HG-induced decrease in the expression levels of both HSP90 and p-Akt,
\end{abstract}

Correspondence to: Professor Chengheng $\mathrm{Hu}$, Department of Cardiology, The First Affiliated hospital, Sun Yat-sen University, Guangdong, 58 Zhongshan 2rd Road, Guangzhou 510080, P.R. China E-mail: huchengheng138@163.com

Professor Ruqiong Nie, Department of Cardiology, Sun Yat-sen Memorial Hospital, Sun Yat-sen Universtity, 107 Yanjiangxi Road, Guangzhou, Guangdong 510120, P.R. China

E-mail: nieruqiong@163.com

*Contributed equally

Key words: hydrogen sulfide, high glucose, $\mathrm{H} 9 \mathrm{c} 2$ cells, heat shock protein, Akt along with inhibition of HG-induced cell injury, as indicated by the increase in cell viability and superoxide dismutase (SOD) activity, and by a decrease in the number of apoptotic cells, reactive oxygen species (ROS) generation, as well as by the decreased dissipation of mitochondrial membrance potential (MMP). Importantly, treatment of the cells with GA or LY294002 (an inhibitor of Akt) prior to exposure to NaHS and HG considerably blocked the cardioprotective effects of NaHS against the HG-induced injury mentioned above. On the whole, the findings of this study demonstrate that the inhibition of the HSP90/Akt pathway may be an important mechanism responsible for HG-induced cardiomyocyte injury. We also provide novel evidence that exogenous $\mathrm{H}_{2} \mathrm{~S}$ protects $\mathrm{H} 9 \mathrm{c} 2$ cells against HG-induced injury by activating the HSP90/Akt pathway.

\section{Introduction}

Hydrogen sulfide $\left(\mathrm{H}_{2} \mathrm{~S}\right)$, the third member of the gaso-transmitter family, is gaining acceptance as a signaling molecule. Increasing evidence has indicated that $\mathrm{H}_{2} \mathrm{~S}$ has a variety of biological effects that may participate in the protection of cardiovascular pathophysilology (1-11). Exogenous $\mathrm{H}_{2} \mathrm{~S}$ has been shown to protect rat hearts against ischemia-reperfusion (IR) injury (4-6) and contributes to the cardioprotective effects of ischemia pre-conditioning in the isolated, perfused rat heart (6). In addition, exogenous $\mathrm{H}_{2} \mathrm{~S}$ ameliorates left ventricular remodeling and dysfunction in the setting of heart failure (12). Recently, we demonstrated that exogenous $\mathrm{H}_{2} \mathrm{~S}$ protects H9c2 cardiac cells against chemical hypoxia (3) or doxorubicin-induced injury $(10,13)$. In recent years, the roles of $\mathrm{H}_{2} \mathrm{~S}$ in diabetes-related cardiovascular complications have attracted considerable attention, since lower circulating $\mathrm{H}_{2} \mathrm{~S}$ levels have been detected in animal models of diabetes (14-16) and patients with type 2 diabetes mellitus (DM) (14,17), and low blood $\mathrm{H}_{2} \mathrm{~S}$ concentrations may be associated with vascular inflammation 
observed in diabetes (14). Importantly, exogenous $\mathrm{H}_{2} \mathrm{~S}$ protects against hyperglycemia-induced vascular endothelial injury (15) and provides protection against myocardial IR-induced damage in $\mathrm{db} / \mathrm{db}$ mice (18) or diabetic rats (19). Furthermore, we recently revealed that exogenous $\mathrm{H}_{2} \mathrm{~S}$ exerts protective effects against high glucose (HG)-induced injury and inflammation in H9c2 cardiac cells $(9,19,20)$. The mechanisms underlying these cardioprotective effects of exogenous $\mathrm{H}_{2} \mathrm{~S}$ are associated with the inhibition of several intracellular signaling pathways, such as mitogen-activated protein kinase (MAPK) (21), leptin (9) and nuclear factor- $\kappa \mathrm{B}(\mathrm{NF}-\kappa \mathrm{B})(20)$. However, the cardioprotective mechanisms of exogenous $\mathrm{H}_{2} \mathrm{~S}$ are complex, and other intracellular signaling pathways may also be involved. Based on the findings introduced in the relative literatures, we speculated that the heat shock protein (HSP)90-serine/threonine protein kinase $(\mathrm{Akt})$ pathway may attribute to the protective effects of exogenous $\mathrm{H}_{2} \mathrm{~S}$ against $\mathrm{HG}$-induced injury to $\mathrm{H} 9 \mathrm{c} 2$ cardiac cells.

HSPs are a family of protective proteins, which constitute an endogenous cellular defense mechanism against hostile environmental stress. HSP90, one of the most abundant cytosolic HSPs, comprises $1-20 \%$ of total proteins in cells (22). Accumulating evidence indicates that HSP90 contributes to cell survival and protection by regulating the folding and stability of various cellular client proteins, including survival and apoptotic factor (23). Hypoxia can increase the expression of HSP90, which efficiently ameliorates myocardial IR-induce myocardial dysfunction (24). The inhibition of HSP90 function with HSP90 inhibitor or HSP90 siRNA markedly diminishes the protective effects of hypoxic pre-conditioning against prolonged hypoxia/reoxygenation-induced injury in $\mathrm{H} 9 \mathrm{C} 2$ cardiac cells (25). Of note, HSP90-endothelial nitric oxide synthase (eNOS) interactions are reduced in endothelial cells cultured in medium containing excess glucose (26). In addition, hyperglycemia impairs ischemic preconditioning (IPC)-elicited cardioprotection by disrupting the association of HSP90 with eNOS in rabbits or mice (27). Of ntoe, in SH-SY5Y cells (28) and the liver (29), $\mathrm{H}_{2} \mathrm{~S}$ has been shown to increase HSP90 expression. In our recent studies, we also revealed that exogenous $\mathrm{H}_{2} \mathrm{~S}$ upregulated the expression levels of HSP90 in PC12 cells (30) and H9c2 cells (3). Importantly, we have demonstrated that HSP90 plays important roles in the protection of exogenous $\mathrm{H}_{2} \mathrm{~S}$ against chemical hypoxia-induced neural (30) or cardiac injury (3). However, whether HSP90 mediates the cardioprotective effects of exogenous $\mathrm{H}_{2} \mathrm{~S}$ against HG-induced injury to $\mathrm{H} 9 \mathrm{c} 2$ cardiac cells remains unknown.

Akt, a serine/threonine kinase, is downstream of phosphatidylinositol 3-kinase (PI3K) to mediate the metabolic action of insulin (31). Impaired insulin-stimulated PI3K/Akt has been reported to be involved in a number of pathological conditions associated with insulin resistance, such as the cardiovascular complication of diabetes $(32,33)$. In addition, in streptozotocintreated rats, diabetic cardiomyopathy is associated with the impaired activation of Akt $(34,35)$. Of note, Akt is one of the HSP90 substrates; thus, HSP90 contributes to the functional stabilization of Akt, the activation of the PI3K/Akt signaling pathways and cell survival. Additionally, HSP90 modulates Akt activity by suppressing its dephosphorylation and proteosomal degradation (36). The HSP90/Akt pathway has been shown to be an important survival and anti-apoptotic pathway in a variety of cells and settings; this pathway has been shown to play a role in myocardial calpain-induced caspase- 3 activation and apoptosis during sepsis (37). Of note, the activation of the Akt pathway also contributes to the cytoprotective effects of $\mathrm{H}_{2} \mathrm{~S}$. In 3T3I1 adipocytes, has been shown to $\mathrm{H}_{2} \mathrm{~S}$ increase glucose utilization by activating the PI3K/Akt pathway (38). Yao et al reported that $\mathrm{H}_{2} \mathrm{~S}$ protected cardiomyocytes from hypoxia/reoxygenation-induced apoptosis via the stimulation of Akt phosphorylation (39). However, whether the HSP90/ Akt pathway contributes to the protective effects of exogenous $\mathrm{H}_{2} \mathrm{~S}$ against $\mathrm{HG}$-induced injury to $\mathrm{H} 9 \mathrm{c} 2$ cardiac cells remains unclear.

The present study was therefore designed to determine the effects of HG on the activation of the HSP90/Akt pathway in $\mathrm{H} 9 \mathrm{c} 2$ cardiac cells and to investigate whether exogenous $\mathrm{H}_{2} \mathrm{~S}$ protects cardiac cells against HG-induced injury by modulating the activity of the HSP90/Akt pathway.

\section{Materials and methods}

Chemicals. NaHS, 5,5',6,6'-tetrachloro-1,1',3,3'-tetraethylimidacarbocyanine iodide (JC-1), Hoechst 33258, the superoxide dismutase (SOD) assay kit, geldanamycin (GA) (an inhibitor of HSP90) and LY294002 [an inhibitor of Akt] were purchased from Sigma-Aldrich (St. Louis, MO, USA). The cell counting kit-8 (CCK-8) was supplied by Dojindo Laboratories (Kumamoto, Japan). Fetal bovine serum (FBS) and Dulbecco's modified Eagle's medium (DMEM) were obtained from Gibco BRL (Grand Island, NY, USA). Anti-phosphorylated (p-)Akt antibody (Cat. no. 12178), anti-Akt antibody (Cat. no. 14702) and anti-HSP90 antibody (Cat. no. 4877) were purchased from Cell Signaling Technology (Boston, MA, USA); horseradish peroxidase (HRP)-conjugated secondary antibody (Cat. no. KC5G5) and the BCA protein assay kit were obtained from KangChen Biotech, Inc. (Shanghai, China). Enhanced chemiluminescence (ECL) solution was purchased from KeyGen Biotech (Nanjing, China). $\beta$-actin (Cat. no. KC-5A08), which was used as a control, was supplied by KangChen Biotech, Inc.

Cell culture and treatment. $\mathrm{H} 9 \mathrm{c} 2$ cardiac cells, a rat cardiac myoblast cell line, were obtained from the Sun Yat-sen University Experimental Animal Center (Guangdong, China). The cells were grown in DMEM supplemented with $10 \%$ FBS under an atmosphere of $5 \% \mathrm{CO}_{2}$ at $37^{\circ} \mathrm{C}$ and $95 \%$ air.

To establish the model of the HG-induced cardiomyocyte injury, the cells were cultured in DMEM (5.5 mM glucose) for $12 \mathrm{~h}$ prior to the administration of $35 \mathrm{mM}$ glucose (final concentration) for $24 \mathrm{~h}$. The glucose concentration of the control group was $5.5 \mathrm{mM}$. To investigate the protective effects of exogenous $\mathrm{H}_{2} \mathrm{~S}$ against $\mathrm{HG}$ ( $35 \mathrm{mM}$ glucose)-induced injury, the cells were treated with $400 \mu \mathrm{M} \mathrm{NaHS}$ (a $\mathrm{H}_{2} \mathrm{~S}$ donor) for $30 \mathrm{~min}$ prior to exposure to $\mathrm{HG}$ for $24 \mathrm{~h}$. To determine whether the HSP90/Akt pathway contributes to the protective effects of $\mathrm{H}_{2} \mathrm{~S}$, the $\mathrm{H} 9 \mathrm{c} 2$ cardiac cells were treated with $1 \mu \mathrm{M}$ GA (an inhibitor of HSP90) or $30 \mu \mathrm{M} \mathrm{LY} 294002$ (an inhibitor of Akt) for $30 \mathrm{~min}$ prior to exposure to NaHS and HG for $24 \mathrm{~h}$.

Western blot analysis. As previously described (40), after being subjected to the indicated treatments, the $\mathrm{H} 9 \mathrm{c} 2$ cardiac cells were 
harvested and lysed with cell lysis solution at $4^{\circ} \mathrm{C}$ for $30 \mathrm{~min}$. The total proteins were quantified using the BCA protein assay kit. Loading buffer was added to cytosolic extracts, and after boiling for approximately $5 \mathrm{~min}$, the same amounts of supernatant from each sample were fractionated by $10 \%$ sodium dodecyl sulphate-polyacrylamide gel electrophoresis (SDS-PAGE), and the total proteins were then transferred onto polyvinylidene difluoride (PVDF) membranes (Miniport; Olympus, Hamburg Germany). The membranes were blocked with $5 \%$ fat-free milk for $60 \mathrm{~min}$ in fresh blocking buffer [0.1\% Tween-20 in Trisbuffered saline (TBS-T)], and incubated with either anti-p-Akt antibody (1:1,000 dilution), anti-Akt antibody (1:1,000 dilution) or anti-HSP90 antibody (1:1,000 dilution) in freshly prepared TBS-T with $3 \%$ fat-free milk overnight with gentle agitation at $4^{\circ} \mathrm{C}$. Glyceraldehyde-3-phosphate dehydrogenase (GAPDH) was used as a control for histone incorporation. GAPDH antibody (Cat. no. KC-5G4) was provided by KeyGen Biotech. The membranes were washed 3 times with TBS-T, successively incubated with HRP-conjugated goat anti-rabbit secondary antibody (1:2,500 dilution) in TBS-T with $3 \%$ fat-free milk for $90 \mathrm{~min}$ at room temperature. The membranes were then washed 3 times with TBS-T for $15 \mathrm{~min}$. The immunoreactive signals were subsequently visualized by ECL detection. In order to quantify protein expression, the X-ray films were scanned and analyzed using Image J $1.47 \mathrm{i}$ software. The experiment was carried out 3 times.

Examination of cell viability. As previously described (40), the $\mathrm{H} 9 \mathrm{c} 2$ cardiac cells were cultured in 96-well plates at a concentration of $1 \times 10^{4}$ cells $/ \mathrm{ml}$, and the CCK- 8 assay was employed to measure the viability of the $\mathrm{H} 9 \mathrm{c} 2$ cells. After being subjected to the indicated treatments, $10 \mu \mathrm{l}$ of CCK- 8 solution at a $1 / 10$ dilution was added to each well and the plate was then incubated for $3 \mathrm{~h}$ in an incubator. The absorbance at $450 \mathrm{~nm}$ was measured using a microplate reader (Molecular Devices, Sunnyvale, CA, USA), The means of the optical density (OD) of 4 wells in the indicated groups were used to calculate the percentage of cell viability according to the following formula: cell viability $(\%)=(\mathrm{OD}$ treatment group/OD control group $\mathrm{x} 100 \%$. The above experiment was repeated 5 times.

Hoechst 33258 nuclear staining for the measurement of apoptosis. Apoptotic cell death was measured by Hoechst 33258 staining followed by photofluorography. In brief, the H9c2 cardiac cells were plated in $35 \mathrm{~mm}$ dishes at a density of $1 \times 10^{6}$ cells/well. After being subjected to the indicated treatments, the $\mathrm{H} 9 \mathrm{c} 2$ cells were cultured with $4 \%$ paraformaldehyde in $0.1 \mathrm{~mol} / 1$ phosphate-buffered saline (PBS, pH 7.4) for $10 \mathrm{~min}$. The slides were then washed 3 times with PBS, followed by staining with $5 \mathrm{mg} / \mathrm{ml}$ Hoechst 33258 for $30 \mathrm{~min}$, The H9c2 cells were washed 3 times with PBS, and the PBS was then discarded and the plates were air dried. Finally, the cells were visualized under a fluorescence microscope (Bx50-FLA; Olympus, Tokyo, Japan). Viable H9c2 cells displayed a uniform blue fluorescence throughout the nucleus and a normal nuclear size; however apoptotic H9c2 cells exhibited condensed, fractured or distorted nuclei. The experiment was carried out 5 times.

Measurement of mitochondrial membrance potential (MMP). MMP was examined using the fluorescent dye, JC-1, a cell-permeable carionic dye that preferentially enters the mitochondria based on the highly negative MMP. The depolarization of MMP results in the loss of MMP from the mitochondria and a decrease in the red/green fluorescence ratio. The H9c2 cells were cultured in a slide with DMEM at a density of $1 \times 10^{6}$ cells/ well. As previously described (40), after being subjected to the indicated treatments, the slides were washed 3 times with PBS, and were then incubated with $1 \mathrm{mg} / \mathrm{JC}-1$ at $37^{\circ} \mathrm{C}$ for $30 \mathrm{~min}$ in an incubator, washed briefly 3 times with PBS and air dried. The fluorescence was measured over the hold field of vision using a fluorescence microscope connected to an imaging system (BX50-FLA; Olympus). The mean fluorescence intensity (MFI) of JC-1 from 3 random fields was analyzed using ImageJ $1.47 \mathrm{i}$ software, and the MFI was taken as an index of the levels of MMP. The experiment was carried out 5 times.

Detection of intracellular reactive oxygen species (ROS) generation. As previously described (40), intracellular ROS generation was examined by the oxidative conversion of cell-permeable oxidation of 2',7'-dichlorodihydrofluorescein diacetate (DCFH-DA) to fluorescent DCF. The H9c2 cells were cultured on a slide with DMEM. After being subjected to the different treatments, the slides were washed 3 times with PBS. DCFH-DA $(10 \mu \mathrm{M})$ solution in serum-free medium was added to the slides, and the H9c2 cells were then incubated at $37^{\circ} \mathrm{C}$ for a further $30 \mathrm{~min}$ in an incubator. The slides were washed 5 times with PBS, and DCF fluorescence was measured over the entire field of vision using a fluorescence microscope connected to an imaging system (BX50-FLA; Olympus). The MFI of ROS from 5 random fields was measured using Image J 1.47i software and the MFI was used as an index of the amount of ROS. The experiment was carried out 5 times.

Measurement of SOD activity. SOD activity was measured by using a SOD assay kit. As previously described (41), after being subjected to the indicated treatments, the cells were washed using PBS and lysed in ice-cold 0.1 M Tris/ $\mathrm{HCl}(\mathrm{pH} 7.4)$ containing $0.5 \%$ Triton-X 100, $5 \mathrm{mM} \beta$-mercaptoethanol and $0.1 \mathrm{mg} / \mathrm{ml}$ phenylmethylsulfonyl fluoride. Lysates were clarified by centrifugation at $14,000 \mathrm{xg}$ at $4^{\circ} \mathrm{C}$ for $5 \mathrm{~min}$ and the cell debris was discarded. SOD activity was detected using a commercial 'SOD assay kit' according to the manufacturer's instructions (Sigma-Aldrich). The absorbance values at $450 \mathrm{~nm}$ were measured using a microplate reader. The experiment was carried out 3 times.

Statistical analysis. All data are presented as the means \pm SEM. Differences between groups were analyzed by one-way analysis of variance (ANOVA) by using SPSS 13.0 (SPSS, Chicago, IL, USA) software, followed by the LSD post hoc comparison test. A value of $\mathrm{p}<0.05$ was considered to indicate a statistically significant difference.

\section{Results}

Exogenous $\mathrm{H}_{2} \mathrm{~S}$ ameliorates the $H G$-induced downregulation of the expression level of HSP9O in H9c2 cardiac cells. To examine the effect of HG ( $35 \mathrm{mM}$ glucose) on the HSP90 expression level in $\mathrm{H} 9 \mathrm{c} 2$ cardiac cells, a time-response experiment on the HSP90 expression level was carried out. After 


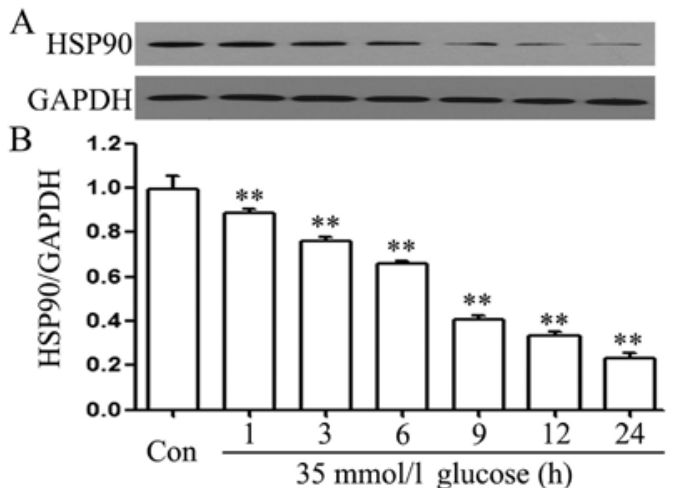

C
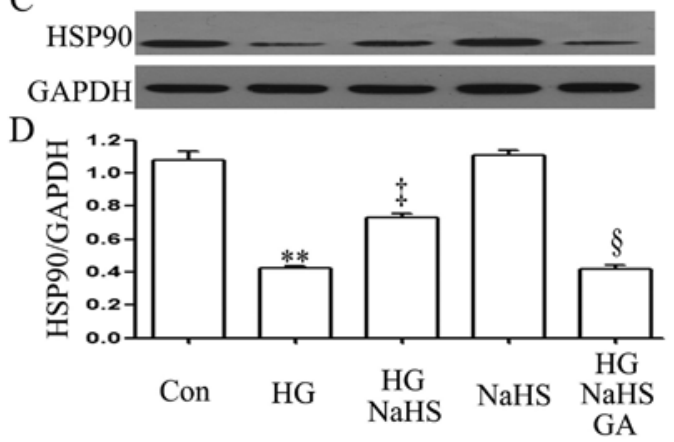

Figure 1. Exogenous hydrogen sulfide $\left(\mathrm{H}_{2} \mathrm{~S}\right)$ attenuates the high glucose (HG)induced decrease in the heat shock protein 90 (HSP90) expression level in H9c2 cardiac cells. (A and C) HSP90 expression levels were semiquantitied by western blot analysis. (A and B) Time course of the changes in HSP90 expression levels induced by HG (35 mM glucose) over a 24 -h time period. (C and D) H9c2 cardiac cells were exposed to HG for $9 \mathrm{~h}$ with or without treatment with $400 \mu \mathrm{M}$ NaHS or without NaHS and geldanamycin (GA) for 30 min prior to exposure to HG. (B and D) Densitometric analysis of the HSP90 expression level in (A and C). Data are presented as the means \pm SEM $(\mathrm{n}=3) .{ }^{* *} \mathrm{p}<0.01$ vs. the control (Con) group; ${ }^{{ }^{*}} \mathrm{p}<0.01$ vs. the HG-treated group; ${ }^{\S} \mathrm{p}<0.01$ vs. the HG + NaHS-treated group.

the cells were exposed to $35 \mathrm{mM}$ glucose for $1,3,6,9,12$ and $24 \mathrm{~h}$, the expression level of HSP90 was decreased in a time-dependent manner (Fig. 1A and B). Importantly, prior to exposure to $35 \mathrm{mM}$ glucose for $9 \mathrm{~h}$, treatment of the cells with $400 \mu \mathrm{M}$ NaHS (a donor of $\mathrm{H}_{2} \mathrm{~S}$ ) for 30 min markedly blocked the HG-induced decrease in the HSP90 expression level (Fig. 1C and D). In addition, treatment of the cells with $1 \mu \mathrm{M}$ GA (an inhibitor of HSP90) for $30 \mathrm{~min}$ prior to exposure to NaHS and HG markedly decreased the expression level of HSP90 which was increased by NaHS (Fig. 1C and D).

Role of HSP9O in the protective effects of exogenous $\mathrm{H}_{2} \mathrm{~S}$ against the $H G$-induced downregulation of ( $p)$-Akt expression in $\mathrm{H} 9 \mathrm{c} 2$ cardiac cells. As shown in Fig. 2A-C, exposure of the H9c2 cardiac cells to $35 \mathrm{mM}$ glucose for $1,3,6,9,12$ and $24 \mathrm{~h}$ induced a decrease in the expression of $\mathrm{p}$-Akt, with the maximal decrease observed at $24 \mathrm{~h}$. However, treatment of the cells with $400 \mu \mathrm{M}$ NaHS for 30 min prior to exposure to HG for $12 \mathrm{~h}$ significantly inhibited the decrease in the expression of p-Akt. Furthermore, treatment of the cells with $1 \mu \mathrm{M}$ GA (an inhibitor of HSP90) for $30 \mathrm{~min}$ prior to exposure to $\mathrm{HG}$ for $12 \mathrm{~h}$ further reduced the decreased $\mathrm{p}$-Akt expression level, suggesting the involvement of endogenous HSP90 in the modulation of Akt activation. Treatment of the cells with
$400 \mu \mathrm{M}$ NaHS alone for 30 min considerably increased the expression level of p-Akt (Fig. 2D-F). In a separate experiment (Fig. 2G-I), we observed that treatment of the $\mathrm{H} 9 \mathrm{c} 2$ cardiac cells with $1 \mu \mathrm{M}$ GA for 30 min prior to exposure to NaHS and HG markedly blocked the increase in p-Akt expression by NaHS. Additionally, treatment of the cells with $30 \mu \mathrm{M}$ LY294002 (an inhibitor of Akt) for $30 \mathrm{~min}$ prior to exposure to $\mathrm{NaHS}$ and $\mathrm{HG}$ also antagonized the promoting effects of NaHS on p-Akt expression.

Roles of the HSP90/Akt pathway in the protective effect of exogenous $\mathrm{H}_{2} \mathrm{~S}$ against $\mathrm{HG}$-induced cytotoxicity in $\mathrm{H} 9 \mathrm{c} 2$ cardiac cells. To determine whether the HSP90/Akt pathway is involved in the protective effects of exogenous $\mathrm{H}_{2} \mathrm{~S}$ against HG-induced cytotoxicity, the H9c2 cardiac cells were treated with GA (an inhibitor of HSP90) or LY294002 (an inhibitor of Akt) prior to exposure to NaHS and HG. As shown in Fig. 3, in agreement with our findings from our recent studies $(9,20)$, treatment of the cells with $400 \mu \mathrm{M}$ NaHS for $30 \mathrm{~min}$ prior to exposure to $35 \mathrm{mM}$ glucose (HG) for $24 \mathrm{~h}$ markedly attenuated HG-induced cytotoxicity, evidenced by an increase in cell viability. However, treatment of the cells with $1 \mu \mathrm{M}$ GA or $30 \mu \mathrm{M}$ LY294002 for $30 \mathrm{~min}$ prior to exposure to NaHS and HG significantly blocked the anti-cytotoxic effects of exogenous $\mathrm{H}_{2} \mathrm{~S}$, leading to a decrease in cell viability. When used alone, GA or LY294002 did not affect the viability of the H9c2 cardiac cells. These results suggest that the HSP90/Akt pathway is involved in the protective effects of exogenous $\mathrm{H}_{2} \mathrm{~S}$ against HG-induced cytotoxicity in H9c2 cardiac cells.

Role of the HSP90/Akt pathway in the protective effects of exogenous $\mathrm{H}_{2} \mathrm{~S}$ against the $\mathrm{HG}$-induced apoptosis in $\mathrm{H} 9 \mathrm{c} 2$ cardiac cells. Consistent with the findings of our recent studies $(9,20)$, treatment of the cells with $400 \mu \mathrm{M}$ NaHS for 30 min prior to exposure to $35 \mathrm{mM}$ glucose (HG) for $24 \mathrm{~h}$ significantly attenuated the $\mathrm{HG}$-induced increase in the number of apoptotic cells, which presented nuclear condensation and fragmentation (Fig. 4C and I). However, the inhibitory effects of NaHS on the HG-induced increase in the number of apoptotic cells were markedly attenuated by treatment of the cells with $1 \mu \mathrm{M}$ GA (Fig. 4D and I) or $30 \mu \mathrm{M}$ LY294002 (Fig. 4E and I) for 30 min prior to exposure to NaHS and HG. The use of GA or LY294002 alone did not significantly alter the percentage of apoptotic H9c2 cardiac cells (Fig. 4G-I). These results indicated that the HSP90/Akt pathway is involved in the protective effect of exogenous $\mathrm{H}_{2} \mathrm{~S}$ against the HG-induced apoptosis of H9c2 cardiac cells.

Role of the HSP90/Akt pathway in the protective effects of exogenous $\mathrm{H}_{2} \mathrm{~S}$ against the $\mathrm{HG}$-induced loss of MMP in $\mathrm{H} 9 \mathrm{c} 2$ cardiac cells. As shown in Fig. 5C and I, treatment of the cells with $400 \mu \mathrm{M}$ NaHS for $30 \mathrm{~min}$ prior to exposure to $\mathrm{HG}$ for $24 \mathrm{~h}$ markedly alleviated the HG-induced mitochondrial insult, as evidenced by a decrease in the dissipation of MMP. Of note, the decreased dissipation of MMP was antagonized by treatment of the cells with $1 \mu \mathrm{M} \mathrm{GA}$ (Fig. 5D and I) or $30 \mu \mathrm{M}$ LY294002 (Fig. 5E and I) for $30 \mathrm{~min}$ prior to exposure to NaHS and $\mathrm{HG}$, suggesting that the HSP90/Akt pathway is involved in the protective effects of exogenous $\mathrm{H}_{2} \mathrm{~S}$ against the $\mathrm{HG}$-induced dissipation of MMP in $\mathrm{H} 9 \mathrm{c} 2$ cardiac cells. 


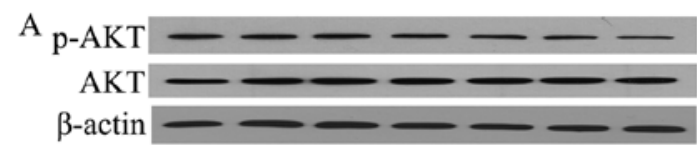

B
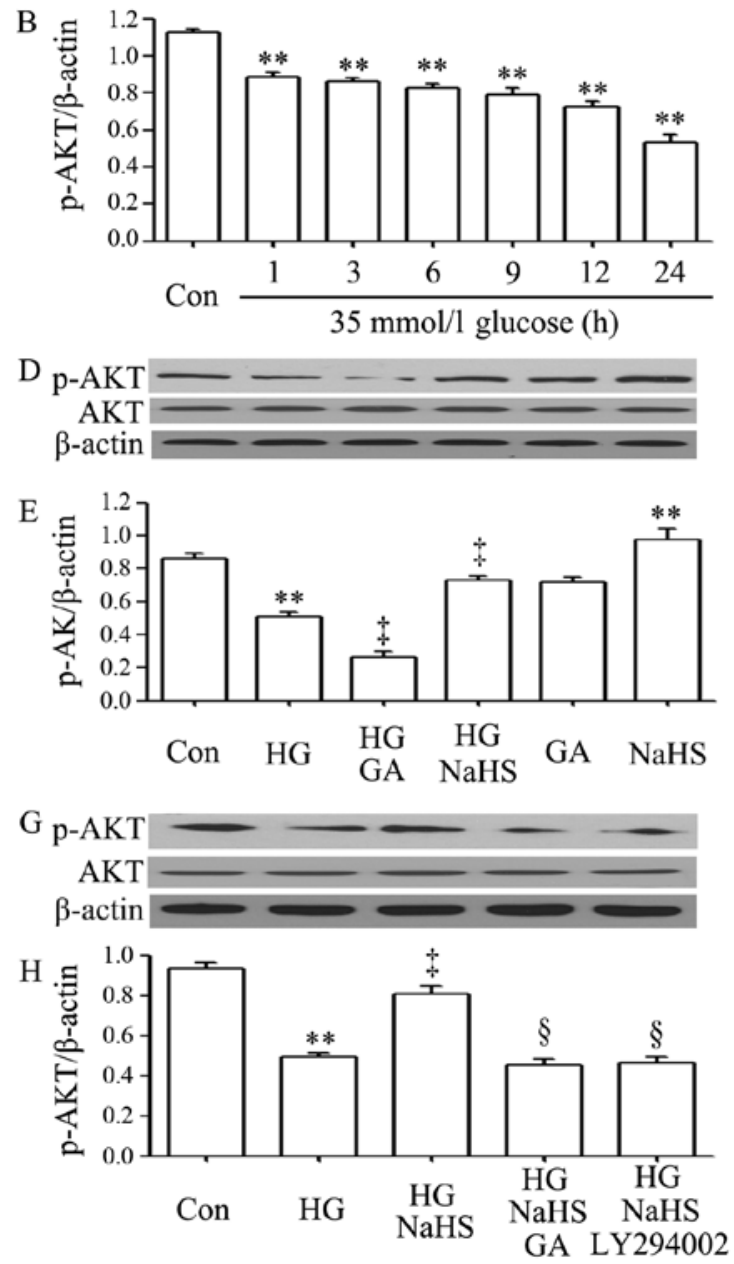
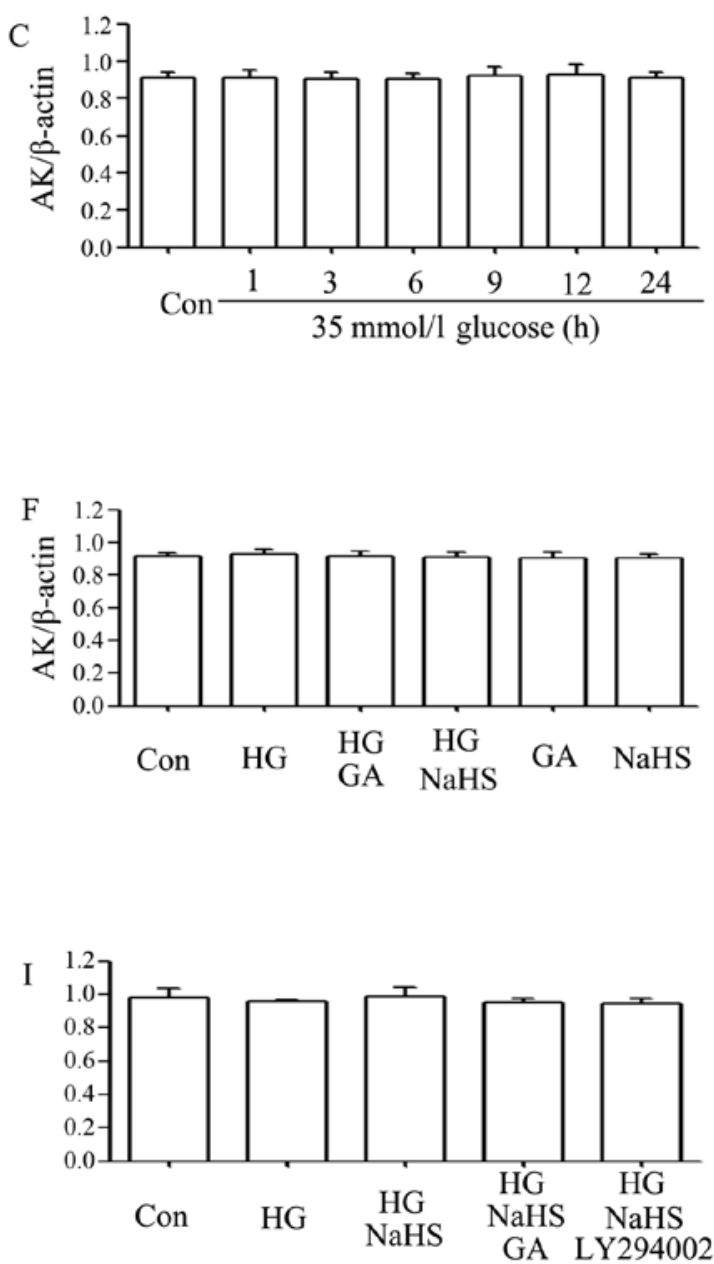

Figure 2. Effects of exogenous hydrogen sulfide $\left(\mathrm{H}_{2} \mathrm{~S}\right)$ and heat shock protein (HSP) inhibitor and Akt inhibitor on the expression levels of phosphorylated Akt in high glucose (HG)-treated H9c2 cardiac cells. (A, D and G) The expression levels of Akt were semiquantitied by western blot analysis. (A-C) Time course of changes in Akt expression levels induced by (HG, $35 \mathrm{mM}$ glucose) over a 24-h time period. (D-F) H9c2 cardiac cells were exposed to HG for $12 \mathrm{~h}$ with or without treatment with $400 \mu \mathrm{M} \mathrm{NaHS}$ or $1 \mu \mathrm{M}$ geldanamycin (GA) for $30 \mathrm{~min}$ prior to exposure to HG for $12 \mathrm{~h}$. (G-I) The cells were exposed to HG for $12 \mathrm{~h}$ with or without treatment with $400 \mu \mathrm{M}$ NaHS or without treatment with NaHS and GA or $30 \mu \mathrm{M} \mathrm{LY} 294002$ for 30 min prior to exposure to HG. (B, C, E, F, H and I) Densitometric analysis of the Akt expression levels in (A, D and G). Data are presented as the means \pm SEM ( $n=3) .{ }^{*}$ p $<0.01$ vs. the control (Con) group; ${ }^{\ddagger} \mathrm{p}<0.01$ vs. the HG-treated group; ${ }^{\S} \mathrm{p}<0.01$ vs. the $\mathrm{HG}+\mathrm{NaHS}-$ treated group.

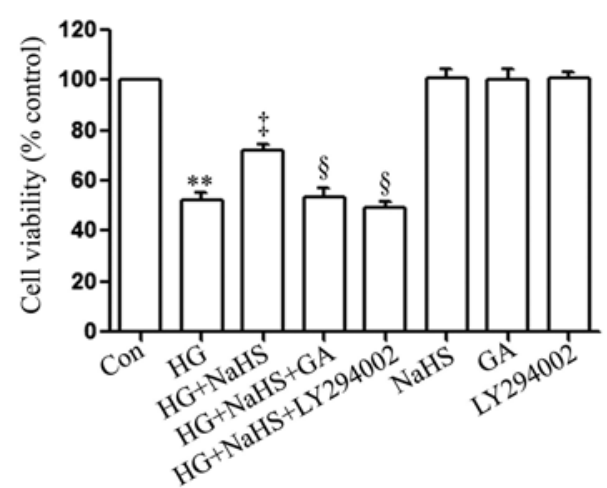

Figure 3. The heat shock protein 90 (HSP90)-Akt pathway contributes to the protection of exogenous hydrogen sulfide $\left(\mathrm{H}_{2} \mathrm{~S}\right)$ against the HG-induced cytotoxicity in $\mathrm{H} 9 \mathrm{c} 2$ cardiac cells. $\mathrm{H} 9 \mathrm{c} 2$ cardiac cells were pre-treated with $1 \mu \mathrm{M}$ geldanamycin (GA) or $30 \mu \mathrm{M}$ LY294002 for $30 \mathrm{~min}$ prior to exposure to $400 \mu \mathrm{M}$ NaHS and HG. Cell viability was tested by CCK- 8 assay. Data are presented as the means $\pm \operatorname{SEM}(n=6) .{ }^{* *} \mathrm{p}<0.01$ vs. the control (Con) group; ${ }^{+} \mathrm{p}<0.01$ vs. the HG-treated group; ${ }^{\S} \mathrm{p}<0.01$ vs. the HG + NaHS-treated group.
Role of the HSP90/Akt pathway in the protective effects of exogenous $\mathrm{H}_{2} \mathrm{~S}$ against $\mathrm{HG}$-induced oxidative stress in $\mathrm{H} 9 \mathrm{C} 2$ cardiac cells. In agreement with the findings of our recent studies $(9,20)$, treatment of the $\mathrm{H} 9 \mathrm{c} 2$ cells with $400 \mu \mathrm{M} \mathrm{NaHS}$ for $30 \mathrm{~min}$ prior to exposure to $35 \mathrm{mM}$ glucose (HG) for $24 \mathrm{~h}$ markedly decreased the generation of intracellular reactive oxygen species (ROS) induced by HG (Fig. 6C and I). Importantly, treatment of the cells with $1 \mu \mathrm{M} \mathrm{GA}$ (Fig. 6D and I) or $30 \mu \mathrm{M}$ LY294002 (Fig. 6E and I) for $30 \mathrm{~min}$ prior to exposure to NaHS and HG markedly blocked the inhibitory effects of NaHS on ROS generation, leading to an increase in ROS generation. When used alone, NaHS, GA or LY294002 did not alter the basal levels of ROS generation (Fig. 6F, G and H).

Role of the HSP90/Akt pathway in the protective effects of exogenous $\mathrm{H}_{2} \mathrm{~S}$ against the $\mathrm{HG}$-induced inhibitory effect on the activity of SOD. SOD is a significant antioxidant system. As 

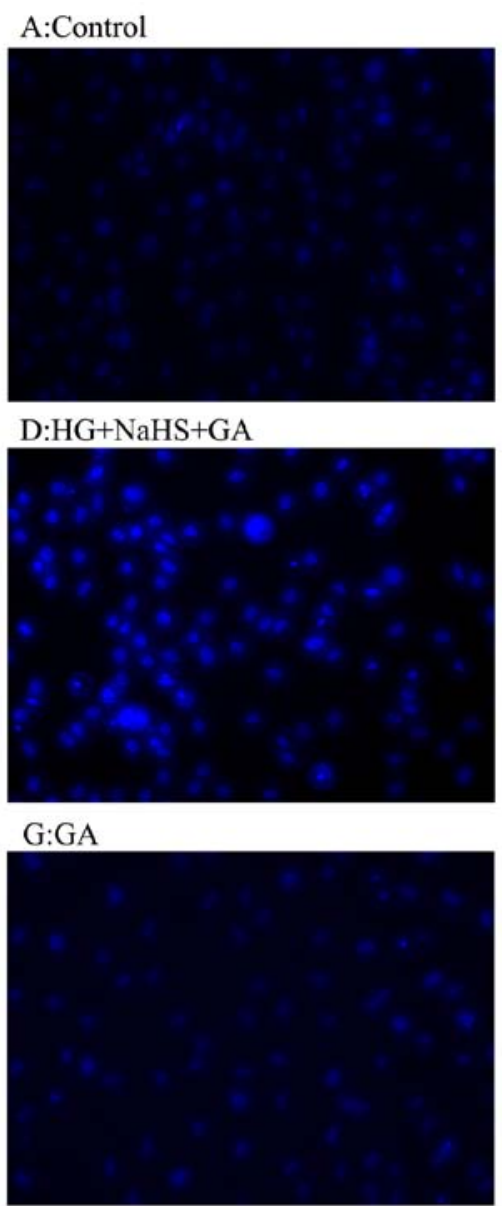

B:HG

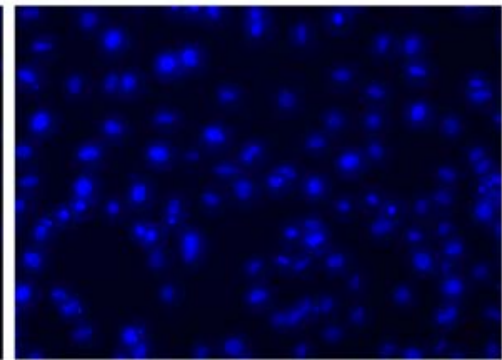

$\mathrm{E}: \mathrm{HG}+\mathrm{NaHS}+\mathrm{LY} 294002$

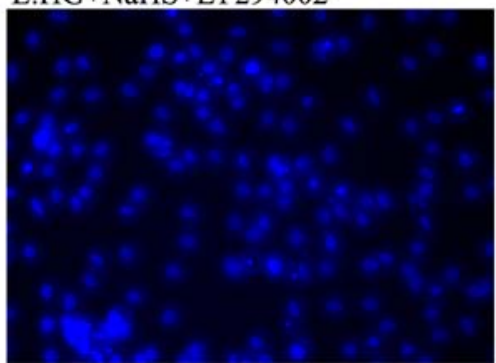

H:LY294002

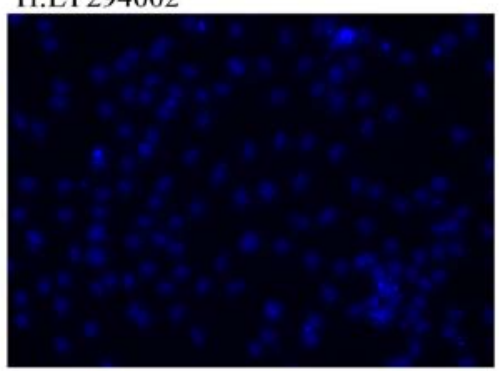

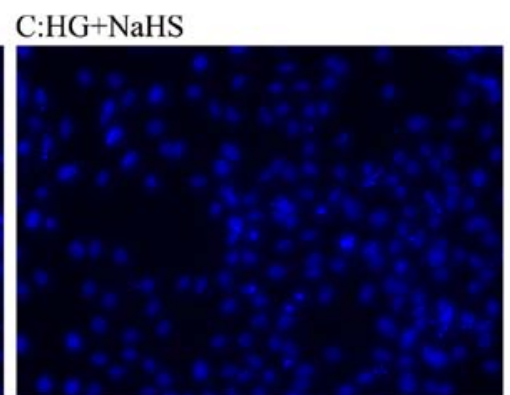

$\mathrm{F}: \mathrm{NaHS}$
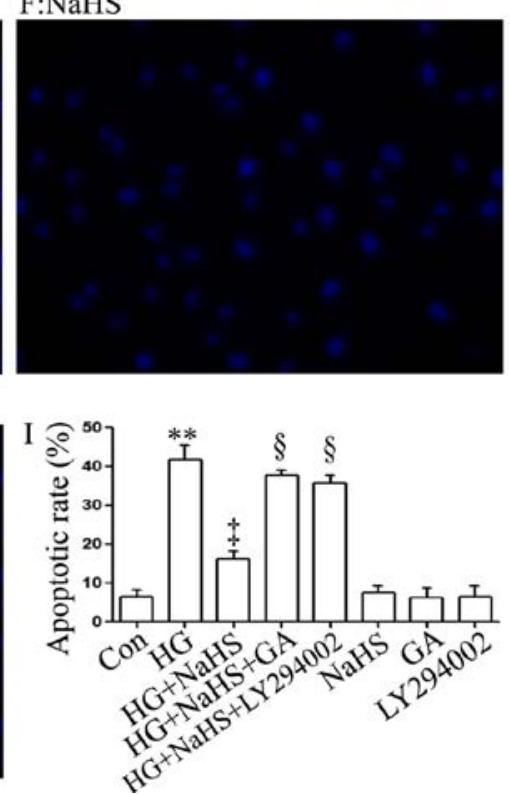

Figure 4. Both heat shock protein (HSP) inhibitor and Akt inhibitor impair the protective effects of exogenous hydrogen sulfide ( $\mathrm{H}_{2} \mathrm{~S}$ ) against the HG-induced apoptosis of $\mathrm{H} 9 \mathrm{c} 2$ cardiac cells. (A-H) Hoechst 33258 nuclear staining followed by photofluorography was carried out to examine cell apoptosis. (A) Control group. (B) H9c2 cardiac cells exposed to $35 \mathrm{mM}$ glucose (HG) for $24 \mathrm{~h}$. (C) Cells treated with $400 \mu \mathrm{M}$ NaHS for $30 \mathrm{~min}$ prior to exposure to HG for $24 \mathrm{~h}$. (D) Cells treated with $1 \mu \mathrm{M}$ geldanamycin (GA) or (E) with $30 \mu \mathrm{M} \mathrm{LY} 294002$ for 30 min prior to exposure to NaHS and HG. (F) Cells treated with $400 \mu \mathrm{M}$ NaHS for $30 \mathrm{~min}$. (G) Cells treated with $1 \mu \mathrm{M}$ GA for $30 \mathrm{~min}$. (H) Cells treated with $30 \mu \mathrm{M}$ LY294002 for 30 min. (I) The apoptotic rate was analyzed using cell counter and ImageJ $1.47 \mathrm{i}$ software. Data are presented as the means \pm SEM $(\mathrm{n}=6)$. ${ }^{* *} \mathrm{p}<0.01 \mathrm{vs}$. the control (Con) group; ${ }^{\star} \mathrm{p}<0.01 \mathrm{vs}$. the HG-treated group; ${ }^{\circledR} \mathrm{p}<0.01 \mathrm{vs}$. the $\mathrm{HG}+\mathrm{NaHS}$-treated group.

shown in Fig. 7, following exposure to $35 \mu \mathrm{M}$ glucose (HG) for $24 \mathrm{~h}$, SOD activity in the H9c2 cardiac cells was considerably decreased compared with that of the control group. Notably, the HG-induced decrease in SOD activity was significantly attenuated by treatment of the cells with $400 \mu \mathrm{M}$ NaHS for $30 \mathrm{~min}$ prior to exposure to $\mathrm{HG}$ for $24 \mathrm{~h}$. However, treatment of the cells with $1 \mu \mathrm{M}$ GA or $30 \mu \mathrm{M}$ LY294002 for 30 min prior to exposure to NaHS and HG markedly hindered the protective effects of NaHS against the HG-induced decrease in SOD activity. When used alone, NaHS, GA or LY294002 did not affect SOD activity in the H9c2 cardiac cells.

\section{Discussion}

Previous studies have demonstrated that HSP90 $(3,24,25,27)$ or Akt $(34,35,37,42,43)$ are cardioprotective and that hyperglycemia impairs HSP90 in endothelial cells (26) and cardiac Akt in streptozotocin-treated rats $(34,35)$. The present study extends the findings of previous studies and provides new evidence that HG-induced $\mathrm{H} 9 \mathrm{c} 2$ cardiomyocyte injury is associated with the impaired HSP90/Akt pathway, as evidenced by the decreased expression levels of HSP90 and Akt. Importantly, we demonstrate exogenous $\mathrm{H}_{2} \mathrm{~S}$ protects $\mathrm{H} 9 \mathrm{c} 2$ cardiac cells against HG-induced injury, by preventing cytotoxicity, apoptosis, ROS overproduction, decreased SOD activity and the dissipation of MMP through the activation of the HSP90/Akt pathway.

Several lines of evidence have demonstrated the cardioprotective effects of HSP90. Hypoxia can enhance the expression of HSP90 (44), which efficiently ameliorates the myocardial I/R-induced myocardial dysfunction (24). Recently, we demonstrated that HSP90 exerts protective effects in H9c2 cardiac cells exposed to chemically-induced hypoxia (3). However, few studies have explored the association between HG-induced cardiovascular injury and HSP90. Mohan et al reported that HG inhibited the HSP90-eNOS interaction in endothelial cells (26). Hyperglycemia attenuates the IPC-induced cardioprotective effects by disrupting the association of HSP90 with eNOS (27). In agreement with previous findings $(26,27)$, our results revealed that $\mathrm{HG}$ inhibited the expression level of HSP90 in H9c2 cardiac cells in a time-dependent manner. To further explore the role of endogenous HSP90 in HG-induced $\mathrm{H} 9 \mathrm{c} 2$ cardiac cell injury, the cells were co-exposed to $\mathrm{HG}$ and GA (an inhibitor of HSP90). Our data revealed that co-treatment of the H9c2 cardiac cells with HG and GA markedly aggra- 
A:Control

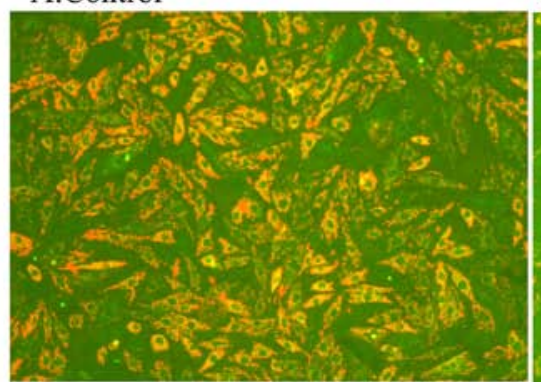

D:HG+NaHS+GA
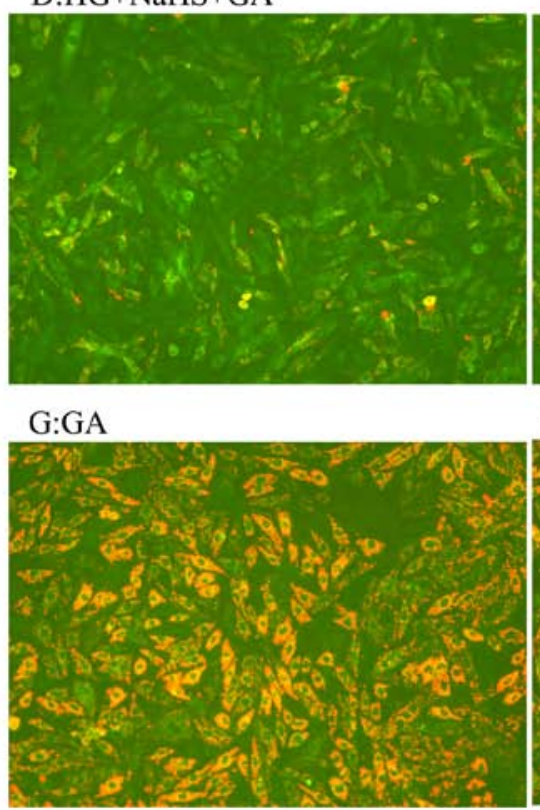

B:HG

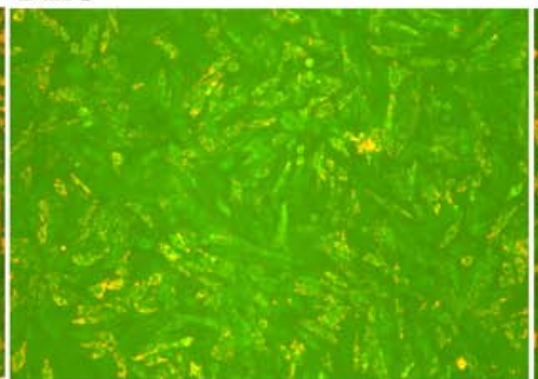

$\mathrm{E}: \mathrm{HG}+\mathrm{NaHS}+\mathrm{LY} 294002$

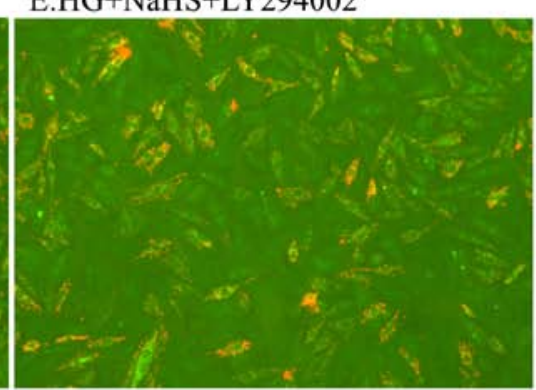

H:LY294002

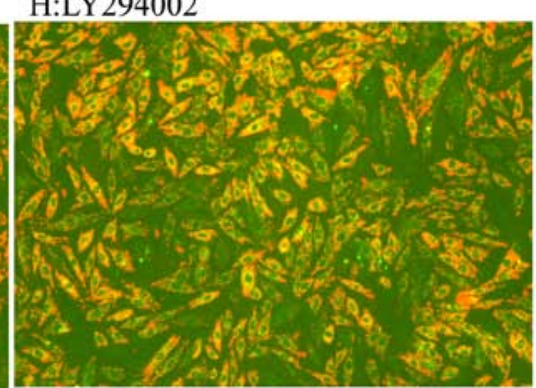

$\mathrm{C}: \mathrm{HG}+\mathrm{NaHS}$

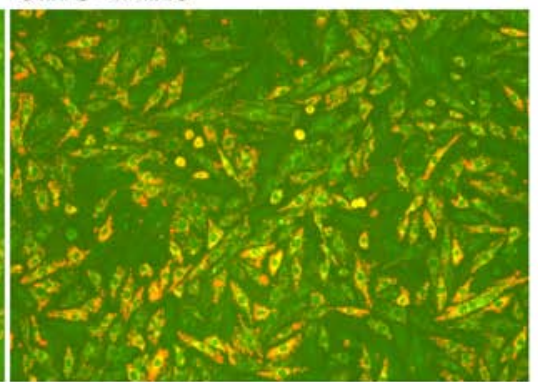

$\mathrm{F}: \mathrm{NaHS}$
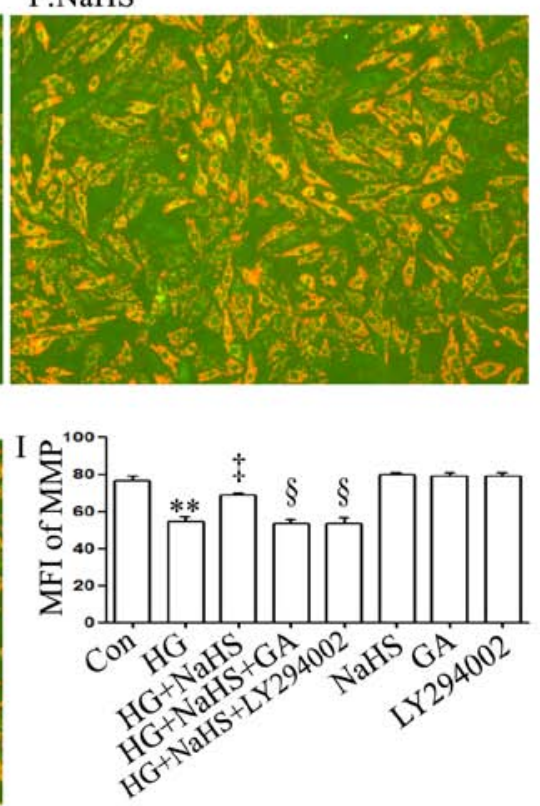

Figure 5. The heat shock protein 90 (HSP90)-Akt pathway attributes to the protective effects of exogenous hydrogen sulfide ( $\mathrm{H}_{2} \mathrm{~S}$ ) against the HG-induced dissipation of mitochondrial membrance potential (MMP) in H9c2 cardiac cells. (A-H) After being subjected to the indicated treatments, MMP was detected by JC-1 statining followed by photography. (A) Control group. (B) H9c2 cardiac cells treated with $35 \mu \mathrm{M}$ glucose (HG) for $24 \mathrm{~h}$. (C) Cells treated with $400 \mu \mathrm{M}$ NaHs for $30 \mathrm{~min}$ prior to exposure to $\mathrm{HG}$ for $24 \mathrm{~h}$. (D) Cells treated with $1 \mu \mathrm{M}$ geldanamycin (GA) for 30 min prior to exposure to NaHs and HG. (E) Cells treated with $30 \mu \mathrm{M}$ LY294002 for 30 min prior to exposure to NaHs and HG. (F) Cells treated with $400 \mu \mathrm{M}$ NaHs for 30 min. (G) Cells treated with $1 \mu \mathrm{M}$ GA for 30 min. (H) Cells treated with $30 \mu \mathrm{M} \mathrm{LY} 294002$ for $30 \mathrm{~min}$. (I) Quantitative analysis of the mean fluorescence intensity (MFI) of JC-1 in (A-H) was carried out using ImageJ $1.47 \mathrm{i}$ software. Data are presented as the means $\pm \mathrm{SEM}(\mathrm{n}=6) .{ }^{* *} \mathrm{p}<0.01 \mathrm{vs}$. the control (Con) group; ${ }^{\star} \mathrm{p}<0.01 \mathrm{vs}$. the HG-treated group; ${ }^{\S} \mathrm{p}<0.01 \mathrm{vs}$. the HG + NaHS-treated group.

vated HG-induced injury, including cyotoxicity, apoptosis, ROS overproduction and the loss of MMP (data not shown). These results suggest that HG-induced cardiomyocyte injury is at least in part associated with the impaired HSP90 pathway.

Since Akt is downstream of PI3K and one of the HSP90 substrates, its roles in cardiovascular protection have also attracted considerable attention. Chanoit et al reported that Akt mediated exogenous zinc-induced cardioprotection against reperfusion injury (45). The Akt pathway is also involved in the cardioprotection of substance $\mathrm{P}$ against ischemic/hypoxia-induced myocardial cell death (46). Moreover, the impaired activation of Akt has been shown to participate in diabetic cardiomyopathy $(34,35)$. Consistent with previous studies $(34,35)$, the present study demonstrated that HG markedly downregulated the expression level of Akt in H9c2 cardiac cells. Additionally, treatment of the cells with GA (an inhibitor of HSP90) prior to exposure to HG markedly aggravated the inhibitory effect of $\mathrm{HG}$ on the expression level of Akt, suggesting the modulatory effect of endogenous HSP90 on Akt activation. To further investigate the role of the impaired Akt pathway in HG-induced cardiomyocyte injury, the cells were co-exposed to HG and LY294002 (an inhibitor of Akt). Our findings indicated that co-treatment of the H9c2 cardiac cells with HG and LY294002 considerably aggravated HG-induced injury, as evidenced by a decrease in cell viability and SOD activity, and an increase in the number of apoptotic cells, ROS generation and the dissipation of MMP (data not shown). Combined with the above-mentioned results that the impaired HSP90 pathway is implicated in HG-induced cardiomyocyte injury, these findings indicate that the impaired HSP90/Akt pathway contributes to HG-induced injury to H9c2 cardiac cells. A recent study demonstrating that the impaired HSP90/ Akt signaling pathway plays a role in the induction of myocardial caspase-3 activation and apoptosis in the septic mice (37) supports our results.

Another novel finding of the present study relates to the role of activation of the HSP90/Akt pathway in the cardioprotective effects of exogenous $\mathrm{H}_{2} \mathrm{~S}$ against $\mathrm{HG}$-induced cardiac injury. As a novel gasomolecule with cardiovascular protective effect, $\mathrm{H}_{2} \mathrm{~S}$ executes the physiological functions of vasorelaxation, cardiopro- 


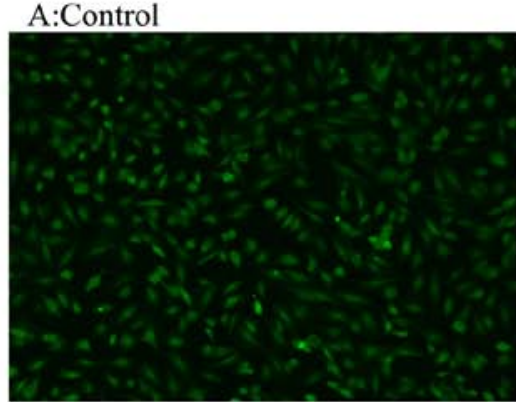

$\mathrm{D}: \mathrm{HG}+\mathrm{NaHS}+\mathrm{GA}$

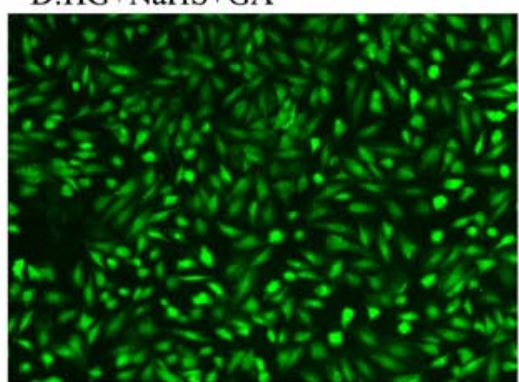

G:GA

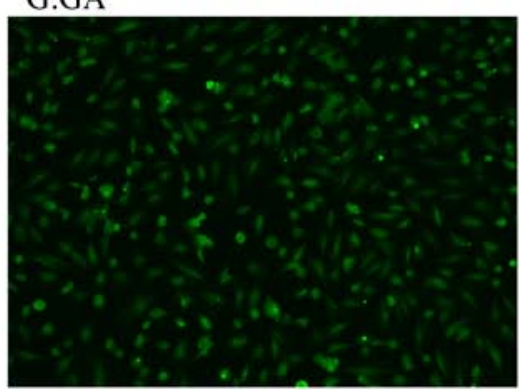

B:HG

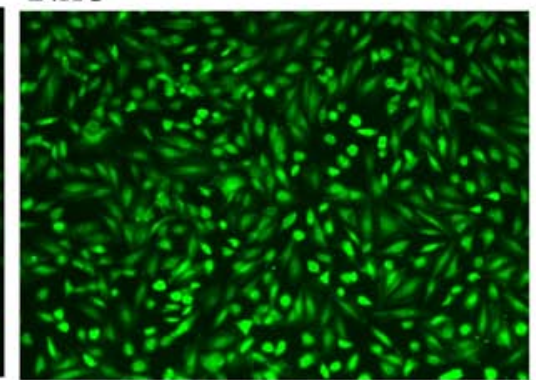

$\mathrm{E}: \mathrm{HG}+\mathrm{NaHS}+\mathrm{LY} 294002$

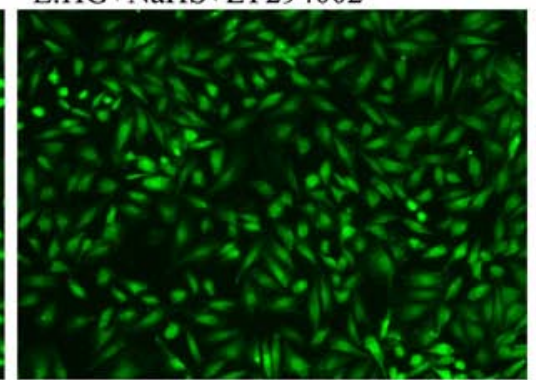

H:LY294002

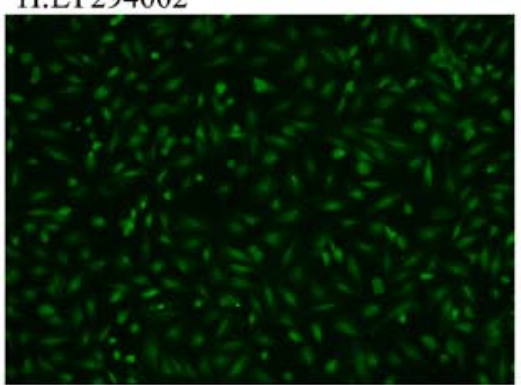

$\mathrm{C}: \mathrm{HG}+\mathrm{NaHS}$

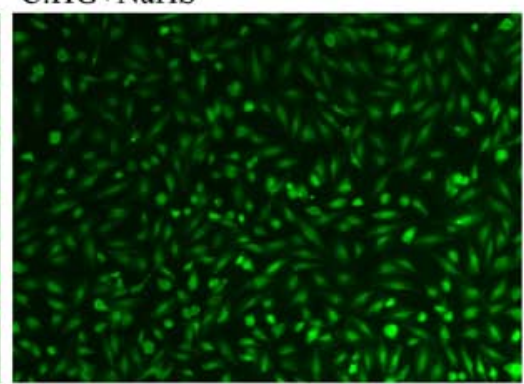

$\mathrm{F}: \mathrm{NaHS}$
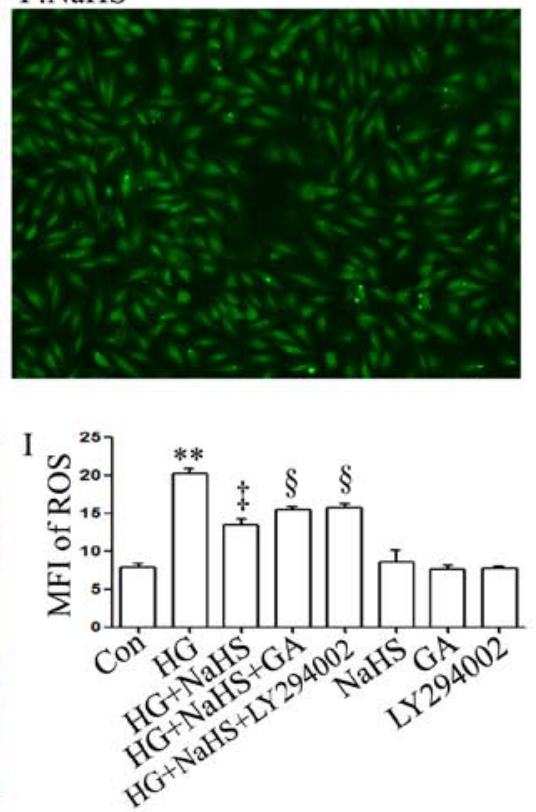

Figure 6. The heat shock protein (HSP)-90-Akt pathway participates in the protective effects of exogenous hydrogen sulfide $\left(\mathrm{H}_{2} \mathrm{~S}\right)$ against the HG-induced an increase in intracellular ROS generation in H9c2 cardiac cells. (A-H) DCF staining followed by photography was carried out to observe the intracellular ROS level. (A) Control group. (B) H9c2 cardiac cells exposed to $35 \mu \mathrm{M}$ glucose (HG) for $24 \mathrm{~h}$. (C) Cells treated with $400 \mu \mathrm{M}$ NaHS for 30 min prior to exposure to HG for $24 \mathrm{~h}$. (D) Cells treated with $1 \mu \mathrm{M}$ geldanamycin (GA) for $30 \mathrm{~min}$ prior to exposure to NaHS and HG. (E) Cells treated with $30 \mu \mathrm{M} \mathrm{LY} 294002$ for 30 min prior to exposure to NaHS and HG. (F) Cells treated with $400 \mu \mathrm{M}$ NaHS for 30 min. (G) Cells treated with $1 \mu \mathrm{M}$ GA for 30 min. (H) Cells treated with $30 \mu \mathrm{M}$ LY294002 for $30 \mathrm{~min}$. (I) Quantitative analysis of mean fluorescence intensity (MFI) was carried out using ImageJ 1.47i software in each group (A-H). Data are presented as the means $\pm \operatorname{SEM}(\mathrm{n}=6) .{ }^{* *} \mathrm{p}<0.01$ vs. the control (Con) group; ${ }^{\star} \mathrm{p}<0.01$ vs. the HG-treated group; ${ }^{\circledR} \mathrm{p}<0.01 \mathrm{vs}$. the HG $+\mathrm{NaHS}$-treated group.

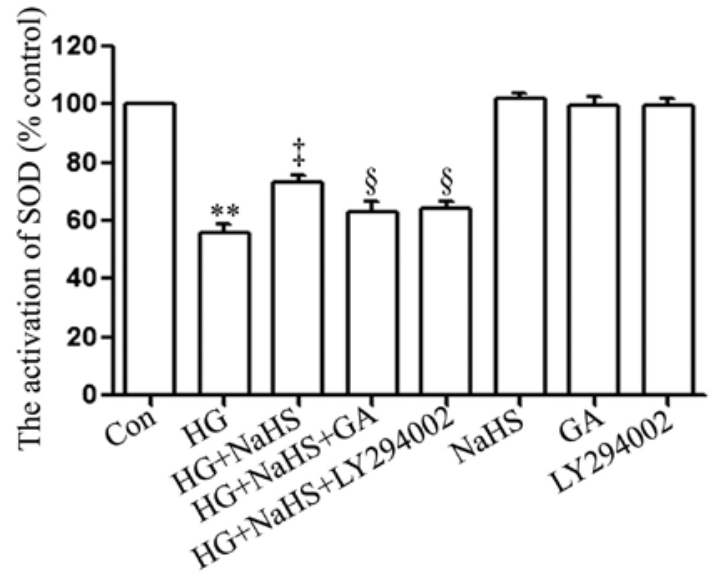

Figure 7. The heat shock protein 90 (HSP90)-Akt pathway plays a role in the protective effecta of exogenous hydrogen sulfide $\left(\mathrm{H}_{2} \mathrm{~S}\right)$ against the HG-induced decrease in superoxide dismutase (SOD) activity in H9c2 cardiac cells. In the indicated group, SOD activity was detected according to the manufacturer's instructions. Data are presented as the means \pm SEM $(n=6) .{ }^{* *} \mathrm{p}<0.01$ vs. the control (Con) group; ${ }^{+} \mathrm{p}<0.01 \mathrm{vs}$. the HG-treated group; ${ }^{\S} \mathrm{p}<0.01 \mathrm{vs}$. the $\mathrm{HG}+\mathrm{NaHS}$-treated group. tection and the inhibition of vascular remodeling (47). Recently, the protective effects of $\mathrm{H}_{2} \mathrm{~S}$ against DM-related cardiovascular damage have received more attention. It has been reported that exogenous $\mathrm{H}_{2} \mathrm{~S}$ diminishes I/R-induced injury in $\mathrm{db} / \mathrm{db}$ mice (18) and diabetic rats (19). Recently, we demonstrated that exogenous $\mathrm{H}_{2} \mathrm{~S}$ protected $\mathrm{H} 9 \mathrm{c} 2$ cardiac cells against HG-induced injury and inflammation by inhibiting the MAPK (19) and NF-кB (20) pathways. However, the mechanisms underlying these cardioprotective effects of $\mathrm{H}_{2} \mathrm{~S}$ are not yet uncompletively clear. Since $\mathrm{H}_{2} \mathrm{~S}$ has been shown to activate HSP90 $(3,28-30)$ or Akt $(38,39)$ in a variety of cells, including cardiomyocytes, and this study demonstrated the involvement of the HSP90/Akt pathway in HG-induced cardiomyocyte insults, this promotes us to further investigate the roles of the HSP90/Akt pathway in the cardioprotective effects of exogenous $\mathrm{H}_{2} \mathrm{~S}$ against HG-induced injury. In agreement with the findings of our recent studies $(19,20)$ and other studies $(9,18,19)$, our results revealed that exogenous $\mathrm{H}_{2} \mathrm{~S}$ exerts protective effects against HG-induced cardiomyocyte injury, leading to an increase in cell viability and SOD activity, 
and a decrease in the number of apoptotic cells, ROS generation and to the decreased dissipation of MMP. Importantly, exogenous $\mathrm{H}_{2} \mathrm{~S}$ markedly blocked the inhibitory effects of $\mathrm{HG}$ on the expression levels of HSP90 and Akt. In order to explore the roles of the HSP90/Akt pathway in the cardioprotective effects of exogenous $\mathrm{H}_{2} \mathrm{~S}$ against HG-induced injuryy, $\mathrm{H} 9 \mathrm{c} 2$ cardiac cells were treated with GA (an inhibitor of HSP90) or LY294002 (an inhibitor of Akt) prior to exposure to NaHS and HG. Our results revealed that both GA and LY294002 markedly attenuated the cardioprotective effects of exogenous $\mathrm{H}_{2} \mathrm{~S}$ against HG-induced injury, resulting in a decrease in cell viability and SOD activity, and in an increase in the number of apoptotic cells, ROS generation and the dissipation of MMP. These results suggest that the activation of the HSP90/Akt pathway plays important roles in the cardioprotective effects of exogenous $\mathrm{H}_{2} \mathrm{~S}$ against HG-induced injury.

Taken together, the findings of this study clearly indicate that the impaired HSP90/Akt pathway may be one of the important mechanisms responsible for HG-induced cardiomyocyte injury. This study also provides evidence that the HSP90/Akt pathway contributes to the cardioprotective effects of exogenous $\mathrm{H}_{2} \mathrm{~S}$ against HG-induced injury, including cytotoxicity, apoptosis, oxidative stress and the dissipation of MMP. Further studies using animal models will likely lead to an improved understanding of this signaling pathway and its newly discovered pathophysiological effects in diabites-related cardiovascular complications.

\section{Acknowledgements}

The present study was supported by grants from the National Natural Science Foundation of China (no. 81270296 and 81370309), Medical Scientific Research Foundation of Guangdong Province (A2015287), Technology Planning Project (201544-01) of Huangpu District, Guangdong Natural Science Foundation (no. S2013010015073) and the Scientific and Technological Projects of Guangzhou City (201604020129).

\section{References}

1. Wang R: Hydrogen sulfide: The third gasotransmitter in biology and medicine. Antioxid Redox Signal 12: 1061-1064, 2010.

2. Li L, Rose P and Moore PK: Hydrogen sulfide and cell signaling. Annu Rev Pharmacol Toxicol 51: 169-187, 2011.

3. Yang Z, Yang C, Xiao L, Liao X, Lan A, Wang X, Guo R, Chen P, $\mathrm{Hu} \mathrm{C}$ and Feng J: Novel insights into the role of HSP90 in cytoprotection of $\mathrm{H}_{2} \mathrm{~S}$ against chemical hypoxia-induced injury in H9c2 cardiac myocytes. Int J Mol Med 28: 397-403, 2011.

4. Zhu YZ, Wang ZJ, Ho P, Loke YY, Zhu YC, Huang SH, Tan CS, Whiteman M, Lu J and Moore PK: Hydrogen sulfide and its possible roles in myocardial ischemia in experimental rats. J Appl Physiol (1985) 102:261-268, 2007.

5. Ji Y, Pang QF, Xu G, Wang L, Wang JK and Zeng YM: Exogenous hydrogen sulfide postconditioning protects isolated rat hearts against ischemia-reperfusion injury. Eur J Pharmacol 587: 1-7, 2008.

6. Bliksøen M, Kaljusto ML, Vaage J and Stensløkken KO: Effects of hydrogen sulphide on ischaemia-reperfusion injury and ischaemic preconditioning in the isolated, perfused rat heart. Eur J Cardiothorac Surg 34: 344-349, 2008.

7. Geng B, Chang L, Pan C, Qi Y, Zhao J, Pang Y, Du J and Tang C: Endogenous hydrogen sulfide regulation of myocardial injury induced by isoproterenol. Biochem Biophys Res Commun 318: 756-763, 2004.

8. Chen SL, Yang CT, Yang ZL, Guo RX, Meng JL, Cui Y, Lan AP, Chen PX and Feng JQ: Hydrogen sulphide protects H9c2 cells against chemical hypoxia-induced injury. Clin Exp Pharmacol Physiol 37: 316-321, 2010.
9. Zhuang XD, Hu X, Long M, Dong XB, Liu DH and Liao XX: Exogenous hydrogen sulfide alleviates high glucose-induced cardiotoxicity via inhibition of leptin signaling in H9c2 cells. Mol Cell Biochem 391: 147-155, 2014.

10. Guo R, Lin J, Xu W, Shen N, Mo L, Zhang C and Feng J: Hydrogen sulfide attenuates doxorubicin-induced cardiotoxicity by inhibition of the p38 MAPK pathway in H9c2 cells. Int J Mol Med 31: 644-650, 2013.

11. Li H, Wang Y, Wei C, Bai S, Zhao Y, Li H, Wu B, Wang R, Wu L and Xu C: Mediation of exogenous hydrogen sulfide in recovery of ischemic post-conditioning-induced cardioprotection via downregulating oxidative stress and up-regulating PI3K/Akt/GSK-3 $\beta$ pathway in isolated aging rat hearts. Cell Biosci 5: 11, 2015.

12. Predmore BL, Kondo K, Bhushan S, Zlatopolsky MA, King AL, Aragon JP, Grinsfelder DB, Condit ME and Lefer DJ: The polysulfide diallyl trisulfide protects the ischemic myocardium by preservation of endogenous hydrogen sulfide and increasing nitric oxide bioavailability. Am J Physiol Heart Circ Physiol 302: H2410H2418, 2012.

13. Wang XY, Yang CT, Zheng DD, Mo LQ, Lan AP, Yang ZL, Hu F, Chen PX, Liao XX and Feng JQ: Hydrogen sulfide protects H9c2 cells against doxorubicin-induced cardiotoxicity through inhibition of endoplasmic reticulum stress. Mol Cell Biochem 363: 419-426, 2012.

14. Jain SK, Bull R, Rains JL, Bass PF, Levine SN, Reddy S, McVie R and Bocchini JA Jr: Low levels of hydrogen sulfide in the blood of diabetes patients and streptozotocin-treated rats causes vascular inflammation? Antioxid Redox Signal 12: 1333-1337, 2010.

15. Suzuki K, Olah G, Modis K, Coletta C, Kulp G, Gerö D, Szoleczky P, Chang T, Zhou Z, Wu L, et al: Hydrogen sulfide replacement therapy protects the vascular endothelium in hyperglycemia by preserving mitochondrial function. Proc Natl Acad Sci USA 108: 13829-13834, 2011.

16. Ahmad FU, Sattar MA, Rathore HA, Abdullah MH, Tan S, Abdullah NA and Johns EJ: Exogenous hydrogen sulfide $\left(\mathrm{H}_{2} \mathrm{~S}\right)$ reduces blood pressure and prevents the progression of diabetic nephropathy in spontaneously hypertensive rats. Ren Fail 34: 203-210, 2012.

17. Whiteman M, Gooding KM, Whatmore JL, Ball CI, Mawson D, Skinner K, Tooke JE and Shore AC: Adiposity is a major determinant of plasma levels of the novel vasodilator hydrogen sulphide. Diabetologia 53: 1722-1726, 2010.

18. Peake BF, Nicholson CK, Lambert JP, Hood RL, Amin H, Amin S and Calvert JW: Hydrogen sulfide preconditions the $\mathrm{db} / \mathrm{db}$ diabetic mouse heart against ischemia-reperfusion injury by activating Nrf2 signaling in an Erk-dependent manner. Am J Physiol Heart Circ Physiol 304: H1215-H1224, 2013.

19. Gao Y, YaoX,Zhang Y,Li W, Kang K, Sun L and Sun X: The protective role of hydrogen sulfide in myocardial ischemia-reperfusion-induced injury in diabetic rats. Int J Cardiol 152: 177-183, 2011.

20. Xu W, Chen J, Lin J, Liu D, Mo L, Pan W, Feng J, Wu W and Zheng D: Exogenous $\mathrm{H}_{2} \mathrm{~S}$ protects $\mathrm{H} 9 \mathrm{c} 2$ cardiac cells against high glucose-induced injury and inflammation by inhibiting the activation of the NF- $\kappa \mathrm{B}$ and IL-1 $\beta$ pathways. Int J Mol Med 35: $177-186,2015$.

21. Zhou X, An G and Lu X: Hydrogen sulfide attenuates the development of diabetic cardiomyopathy. Clin Sci (Lond) 128: 325-335, 2015.

22. Piper PW: The Hsp90 chaperone as a promising drug target. Curr Opin Investig Drugs 2: 1606-1610, 2001.

23. Terasawa K, Minami $M$ and Minami Y: Constantly updated knowledge of Hsp90. J Biochem 137: 443-447, 2005.

24. Kupatt C, Dessy C, Hinkel R, Raake P, Daneau G, Bouzin C, Boekstegers $\mathrm{P}$ and Feron O: Heat shock protein 90 transfection reduces ischemia-reperfusion-induced myocardial dysfunction via reciprocal endothelial NO synthase serine 1177 phosphorylation and threonine 495 dephosphorylation. Arterioscler Thromb Vasc Biol 24: 1435-1441, 2004.

25. Jiao JD, Garg V, Yang B and Hu K: Novel functional role of heat shock protein 90 in ATP-sensitive $\mathrm{K}^{+}$channel-mediated hypoxic preconditioning. Cardiovasc Res 77: 126-133, 2008.

26. Mohan S, Konopinski R, Yan B, Centonze VE and Natarajan M: High glucose-induced IKK-Hsp-90 interaction contributes to endothelial dysfunction. Am J Physiol Cell Physiol 296: C182-C192, 2009.

27. Vladic N, Ge ZD, Leucker T, Brzezinska AK, Du JH, Shi Y, Warltier DC, Pratt PF Jr and Kersten JR: Decreased tetrahydrobiopterin and disrupted association of Hsp90 with eNOS by hyperglycemia impair myocardial ischemic preconditioning. Am J Physiol Heart Circ Physiol 301: H2130-H2139, 2011. 
28. Tay AS, Hu LF, Lu M, Wong PT and Bian JS: Hydrogen sulfide protects neurons against hypoxic injury via stimulation of ATP-sensitive potassium channel/protein kinase C/extracellular signal-regulated kinase/heat shock protein 90 pathway. Neuroscience 167: 277-286, 2010.

29. Jha S, Calvert JW, Duranski MR, Ramachandran A and Lefer DJ: Hydrogen sulfide attenuates hepatic ischemia-reperfusion injury: Role of antioxidant and antiapoptotic signaling. Am J Physiol Heart Circ Physiol 295: H801-H806, 2008.

30. Meng JL, Mei WY, Dong YF, Wang JH, Zhao CM, Lan AP, Yang CT, Chen PX, Feng JQ and $\mathrm{Hu} \mathrm{CH}$ : Heat shock protein 90 mediates cytoprotection by $\mathrm{H}_{2} \mathrm{~S}$ against chemical hypoxia-induced injury in PC12 cells. Clin Exp Pharmacol Physiol 38: 42-49, 2011.

31. Dummler B and Hemmings BA: Physiological roles of PKB/Akt isoforms in development and disease. Biochem Soc Trans 35: 231-235, 2007.

32. Semple D, Smith K, Bhandari S and Seymour AM: Uremic cardiomyopathy and insulin resistance: A critical role for akt? J Am Soc Nephrol 22: 207-215, 2011.

33. Yu Q, Gao F and Ma XL: Insulin says NO to cardiovascular disease. Cardiovasc Res 89: 516-524, 2011.

34. Laviola L, Belsanti G, Davalli AM, Napoli R, Perrini S, Weir GC, Giorgino R and Giorgino F: Effects of streptozocin diabetes and diabetes treatment by islet transplantation on in vivo insulin signaling in rat heart. Diabetes 50: 2709-2720, 2001

35. Gurusamy N, Watanabe K, Ma M, Prakash P, Hirabayashi K, Zhang S, Muslin AJ, Kodama M and Aizawa Y: Glycogen synthase kinase 3 beta together with 14-3-3 protein regulates diabetic cardiomyopathy: Effect of losartan and tempol. FEBS Lett 580: 1932-1940, 2006.

36. Jeon YK, Park CH, Kim KY, Li YC, Kim J, Kim YA, Paik JH, Park BK, Kim CW and Kim YN: The heat-shock protein 90 inhibitor, geldanamycin, induces apoptotic cell death in Epstein-Barr virus-positive NK/T-cell lymphoma by Akt down-regulation. J Pathol 213: 170-179, 2007.

37. Li X, Luo R, Jiang R, Meng X, Wu X, Zhang S and Hua W: The role of the Hsp90/Akt pathway in myocardial calpaininduced caspase-3 activation and apoptosis during sepsis. BMC Cardiovasc Disord 13: 8, 2013.

38. Manna P and Jain SK: Hydrogen sulfide and L-cysteine increase phosphatidylinositol 3,4,5-trisphosphate (PIP3) and glucose utilization by inhibiting phosphatase and tensin homolog (PTEN) protein and activating phosphoinositide 3-kinase (PI3K)/serine/threonine protein kinase $(\mathrm{AKT}) /$ protein kinase $\mathrm{C} \xi / \lambda(\mathrm{PKC} \zeta / \lambda)$ in $3 \mathrm{~T} 311$ adipocytes. J Biol Chem 286: 39848-39859, 2011.
39. Yao LL, Huang XW, Wang YG, Cao YX, Zhang CC and Zhu YC: Hydrogen sulfide protects cardiomyocytes from hypoxia/reoxygenation-induced apoptosis by preventing GSK-3beta-dependent opening of mPTP. Am J Physiol Heart Circ Physiol 298: H1310-H1319, 2010.

40. Chen J, Guo R, Yan H, Tian L, You Q, Li S, Huang R and Wu K: Naringin inhibits ROS-activated MAPK pathway in high glucose-induced injuries in $\mathrm{H} 9 \mathrm{c} 2$ cardiac cells. Basic Clin Pharmacol Toxicol 114: 293-304, 2014.

41. Chen PM, Wu TC, Wang YC, Cheng YW, Sheu GT, Chen CY and Lee $\mathrm{H}$ : Activation of NF- $\kappa$ B by SOD2 promotes the aggressiveness of lung adenocarcinoma by modulating NKX2-1-mediated IKK $\beta$ expression. Carcinogenesis 34: 2655-2663, 2013

42. Armstrong SC: Protein kinase activation and myocardial ischemia/reperfusion injury. Cardiovasc Res 61: 427-436, 2004.

43. Bae S and Zhang L: Gender differences in cardioprotection against ischemia/reperfusion injury in adult rat hearts: Focus on Akt and protein kinase $\mathrm{C}$ signaling. J Pharmacol Exp Ther 315: 1125-1135, 2005.

44. Chen JX and Meyrick B: Hypoxia increases Hsp90 binding to eNOS via PI3K-Akt in porcine coronary artery endothelium. Lab Invest 84: 182-190, 2004.

45. Chanoit G, Lee S, Xi J, Zhu M, McIntosh RA, Mueller RA, Norfleet EA and Xu Z: Exogenous zinc protects cardiac cells from reperfusion injury by targeting mitochondrial permeability transition pore through inactivation of glycogen synthase kinase-3beta. Am J Physiol Heart Circ Physiol 295: H1227-H1233, 2008.

46. Jubair S, Li J, Dehlin HM, Manteufel EJ, Goldspink PH, Levick SP and Janicki JS: Substance P induces cardioprotection in ischemia-reperfusion via activation of AKT. Am J Physiol Heart Circ Physiol 309: H676-H684, 2015.

47. Zhuo Y, Chen PF, Zhang AZ, Zhong H, Chen CQ and Zhu YZ: Cardioprotective effect of hydrogen sulfide in ischemic reperfusion experimental rats and its influence on expression of survivin gene. Biol Pharm Bull 32: 1406-1410, 2009. 